\title{
Starches Modified by Combination of Phosphorylation and High-Voltage Electrical Discharge (HVED) Treatment
}

\author{
Ivanka Grgićl ${ }^{\oplus}$, Marijana Grec ${ }^{2} \odot$, Artur Gryszkin ${ }^{3}$, Tomasz Zięba ${ }^{3} \odot$, Mirela Kopjar $^{2} \odot$,

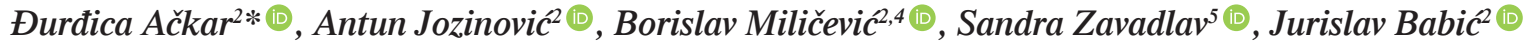 \\ IInstitute of Public Health Brod-Posavina County, V. Nazora 2A, 35000 Slavonski Brod, Croatia \\ ${ }^{2}$ Department of Food Technologies, Faculty of Food Technology Osijek, \\ Josip Juraj Strossmayer University of Osijek, F. Kuhača 18, 31000 Osijek, Croatia \\ ${ }^{3}$ Department of Food Storage and Technology, Wrocław University of Environmental and Life Sciences, \\ ul. Chetmonskiego 37/41, 51-630 Wroctaw, Poland \\ ${ }^{4}$ Polytechnic in Požega, Vukovarska ulica 17, 34000 Požega, Croatia \\ ${ }^{5}$ Department of Food Technology, Karlovac University of Applied Sciences, \\ $\operatorname{Trg}$ J. J. Strossmayera 9, 47000 Karlovac, Croatia
}

Key words: cereal starch, tuber starch, HVED, phosphorylation, physicochemical properties

\begin{abstract}
Starch is extensively used in the food industry as a texture modifier, a fat substitute, and in other applications. To optimise starch functional properties for specific use, it is subjected to various modifications. High-voltage electrical discharge (HVED) treatment, as a non-thermal and rapid process, was applied in this research as a single method and in combination with phosphorylation in order to explore its potential for improving starch physicochemical properties. Maize, wheat, potato, and tapioca starches were modified, and $\mathrm{Na}_{5} \mathrm{P}_{3} \mathrm{O}_{10}$ and $\mathrm{Na}_{2} \mathrm{HPO}_{4}$ were used for phosphorylation. Starch gelatinisation parameters (by DSC); paste clarity; and contents of amylose, damaged starch, and resistant starch were determined; and FTIR-ATR spectra were recorded. All modifications reduced the enthalpy of gelatinisation and decreased contents of amylose, resistant starch, and damaged starch. The effect of the HVED treatment on starch properties depended on starch type and combinations with chemicals. HVED could act as an aid in the starch phosphorylation process since the properties analysed were more effectively improved when HVED was combined with phosphorylation than by phosphorylation alone.
\end{abstract}

\section{ABBREVIATIONS}

HVED - High-voltage electrical treatment, DSC - Differential scanning calorimetry, FTIR-ATR - Fourier-transform infrared spectroscopy-attenuated total reflectance, and $\% \mathrm{~T}-\%$ transmittance.

\section{INTRODUCTION}

Starch has an already well established role in food, pharmaceutical, paper, and packaging industries; however, in its native form it often does not come up to desired functional properties. Therefore, different modifications have been applied to improve its properties, including mainly chemical processes. Increasing demands for reducing chemical usage, waste generation, and energy exploitation have led to novel technique applications in all aspects of food processing and production. High-voltage electrical discharge (HVED)

\footnotetext{
* Corresponding Author:

E-mail: dackar@ptfos.hr (Đ. Ačkar)
}

treatment has emerged as one of the non-thermal and rapid techniques applicable in decontamination of food, waste treatment, and extraction of bioactive compounds [Barišić et al., 2020]. It is a process of releasing energy between two electrodes submerged in a liquid medium [Rosello-Soto et al., 2015], which leads to the disruption of organic cells and enhanced extraction of different compounds. In addition, electrical discharge causes the formation of electrically-charged compounds (ions, free radicals), which induce chemical changes of the treated material. Most often, a pin-to-plate configuration is used, generating direct current glow or pulsed corona [Vanraes et al., 2016]. If gas is available (air, $\mathrm{N}_{2}, \mathrm{CO}_{2}, \mathrm{Ar}$, etc.) during the HVED treatment, plasma will be generated. There is a significant number of articles dealing with the influence of cold plasma on starch properties, with reported changes in starch structure, accompanied with cross-linking and/or formation of new functional groups [Bie et al., 2016a,b; Khorram et al., 2015; Thirumdas et al., 2017]. However, to the best of authors' knowledge, there is no relevant data on the influence of other types of HVED or combination of HVED with chemical 
modification of starch. The aim of this research was, therefore, to explore if HVED treatment in a water suspension induces changes in the physicochemical properties of starch, how it reflects on starch properties, and if it may be used as an aid in chemical modification of starch to increase process efficiency, by activating starch molecules. Phosphorylation of starch with $\mathrm{Na}_{5} \mathrm{P}_{3} \mathrm{O}_{10}$ or $\mathrm{Na}_{2} \mathrm{HPO}_{4}$ was chosen for the research because it has been reported that these modifications also result in a combined effect of cross-linking and substitution [Sechi \& Marques, 2017]. The additional treatment of HVED could favour one of the reactions, enabling easier control of the process and obtaining a desired compound (cross-linked or substituted).

\section{MATERIAL AND METHODS}

\section{Materials and chemicals}

Tapioca, potato, and maize starches were kindly provided by Cargill (Minneapolis, MN, USA). Wheat starch was isolated at the Faculty of Food Technology Osijek, Josip Juraj Strossmayer University of Osijek (Croatia) as described in our previous paper [Ačkar et al., 2010]. $\mathrm{Na}_{5} \mathrm{P}_{3} \mathrm{O}_{10}$ or $\mathrm{Na}_{2} \mathrm{HPO}_{4}$ used for phosphorylation were obtained from Acros Organics (Geel, Belgium). Resistant starch assay kit, amylose/amylopectin assay kit, and starch damage assay kit were purchased in Megazyme (Bray, Ireland).

\section{High-voltage electrical discharge (HVED) treatment of starch}

Starch was suspended in demineralised water $(1 \mathrm{~g} / \mathrm{mL})$ and treated with HVED $(30 \mathrm{kV}, 70 \mathrm{~Hz}, 30 \mathrm{~min})$ with stirring at a magnetic stirrer. The HVED device was custom-made for the Faculty of Food Technology in Osijek by Inganiare CPTS1. It consists of a chamber, containing a stainless steel needle (diameter $2.5 \mathrm{~mm}$ ) and a plate electrode (diameter $45 \mathrm{~mm}$ ), connected to a high-voltage pulse generator. The distance between the electrodes during all treatments was $2 \mathrm{~cm}$. After treatment, the starch suspension was centrifuged at $3000 \mathrm{rpm} / 5 \mathrm{~min}$ (Centra MP4R, IEC, Needham Heights, MA, USA) to remove excess water, air-dried overnight, and then dried in the oven at $130^{\circ} \mathrm{C}$ until the moisture content of $<85 \mathrm{~g} / 100 \mathrm{~g}$ was achieved.

\section{Phosphorylation of starch with $\mathrm{Na}_{5} \mathbf{P}_{3} \mathbf{O}_{10}$}

Starch was phosphorylated with $\mathrm{Na}_{5} \mathrm{P}_{3} \mathrm{O}_{10}$ according to the method described by Lim \& Seib [1993]. Briefly, $2.5 \mathrm{~g}$ of $\mathrm{Na}_{5} \mathrm{P}_{3} \mathrm{O}_{10}$ and $2.5 \mathrm{~g}$ of $\mathrm{Na}_{2} \mathrm{SO}_{4}$ was dissolved in $200 \mathrm{~mL}$ of demineralised water. Next, $100 \mathrm{~g}$ of starch was suspended in the solution by stirring at a magnetic stirrer for $20 \mathrm{~min}$. The $\mathrm{pH}$ value of the suspension was set to 10.0 by drop-wise adding of $\mathrm{NaOH}(0.45 \mathrm{M})$, and the suspension was stirred for another hour. Then, it was centrifuged at $3000 \mathrm{rpm}$ for 5 min (IEC Centra MP4R), water was discarded, and starch was air-dried overnight and thermally-treated at $130^{\circ} \mathrm{C} / 2 \mathrm{~h}$. Starch was then suspended in $250 \mathrm{~mL}$ of water, centrifuged, and washed three times with water. Thus obtained starch was dried at ambient temperature until the moisture content of $<85 \mathrm{~g} / 100 \mathrm{~g}$ was achieved.

\section{Phosphorylation of starch with $\mathrm{Na}_{2} \mathrm{HPO}_{4}$}

Phosphorylation with $\mathrm{Na}_{2} \mathrm{HPO}_{4}$ was conducted according to the method described by Sung et al. [2005] and Prasanthi \& Rama Rao [2010] with slight modifications. Briefly, starch (100 g) and $\mathrm{Na}_{2} \mathrm{HPO}_{4}$ were suspended in $200 \mathrm{~mL}$ of demineralised water and stirred at a magnetic stirrer for $30 \mathrm{~min}$. The suspension was centrifuged, starch was thermally treated and washed as described above.

\section{Combinations of HVED treatment and phosphorylations}

When starch was first treated with HVED, a suspension was prepared as described in the "High-voltage electrical discharge (HVED) treatment of starch" section and then phosphorylated with $\mathrm{Na}_{5} \mathrm{P}_{3} \mathrm{O}_{10}$ or $\mathrm{Na}_{2} \mathrm{HPO}_{4}$. When starch was first phosphorylated, the chemical modification with $\mathrm{Na}_{5} \mathrm{P}_{3} \mathrm{O}_{10}$ or $\mathrm{Na}_{2} \mathrm{HPO}_{4}$ was done prior to the HVED treatment.

\section{Differential scanning calorimetry (DSC) analysis}

A DSC 822E differential scanning calorimeter (Mettler Toledo, Giessen, Germany) was used to determine gelatinisation parameters of starches. Samples were analysed without pretreatment, as dry powders. Starch (on dry matter d.m. - basis) and water were mixed in a ratio of 1:3 $(w / w)$ in standard Al-crucibles (40 $\mu \mathrm{L})$, hermetically sealed, and equilibrated at ambient conditions for $20 \mathrm{~min}$. An empty aluminium pan was used as a reference. Starch samples were heated at the rate of $4^{\circ} \mathrm{C} / \mathrm{min}$ from $25^{\circ} \mathrm{C}$ to $100^{\circ} \mathrm{C}$ and changes in enthalpy ( $\Delta \mathrm{H}$ in $\mathrm{J} / \mathrm{g} \mathrm{d}$.m. of starch), onset temperature $\left(\mathrm{t}_{\mathrm{o}}\right)$, peak temperature $\left(\mathrm{t}_{\mathrm{p}}\right)$, and endset temperature $\left(\mathrm{t}_{\mathrm{e}}\right)$ were obtained from the exotherm DSC curves. Analyses were done in triplicates.

\section{Paste clarity determination}

Paste clarity was determined (in triplicates) according to the method described by Raina et al. [2006]. To this end, $1 \%$ starch suspensions (on starch d.m. basis) were heated for $30 \mathrm{~min}$ in boiling shaking water bath (200 rpm). After 1-h holding at room temperature, $\%$ transmittance $(\% \mathrm{~T})$ was measured at $650 \mathrm{~nm}$ against distilled water as a blank (Camspec M501 spectrophotometer, Leeds, UK).

\section{Determination of contents of amylose, damaged starch, and resistant starch}

Megazyme kits were used for analyses. Amylose content was determined according to the method described by Gibson et al. [1997]. Amylopectin was precipitated with concanavalin A and separated from amylose by centrifugation. Both amylose and amylopectin were enzymatically hydrolysed to glucose, which was measured spectrophotometrically (Camspec M501 spectrophotometer) after reaction with glucose oxidase with peroxidase and 4-aminoantipyrine reagent. Damaged starch content was determined according to the American Association of Cereal Chemists Method 76-31.01 [AACC, 2010] and resistant starch content according to the Association of Official Analytical Chemists Method 2002.02 [AOAC, 2005]. The contents of amylose (\%), damaged starch (\%), and resistant starch (g/100 g d.m.) were determined in triplicates. 
Fourier-transform infrared spectroscopy-attenuated total reflectance (FTIR-ATR) analysis

FTIR-ATR spectra were recorded using a Cary 630 spectrometer (Agilent, Santa Clara, CA, USA) in the range of 4000-650 $\mathrm{cm}^{-1}$. In total, 32 spectra of each sample were recorded and averaged with a spectral resolution of $16 \mathrm{~cm}^{-1}$. Samples were analysed without pretreatment, as dry powders.

\section{Statistical analysis}

All modifications were repeated three times, and for each modification one composite sample was made and taken for further analysis. All analyses were done in triplicates, and the results obtained were statistically analysed by the analysis of variance and Fischer LSD test $(\mathrm{p}<0.05)$ in Statistica ${ }^{\circledR}$ 13 software (TIBCO Software Inc., Palo Alto, CA, USA). Results are expressed as mean value \pm standard deviation.

\section{RESULTS AND DISCUSSION}

In order to explore HVED influence on starch properties and the potential of combining HVED with chemical modifications, four starch types (maize, wheat, potato, and tapioca) were treated with HVED alone, phosphorylated $\left(\mathrm{Na}_{5} \mathrm{P}_{3} \mathrm{O}_{10}\right.$ or $\mathrm{Na}_{2} \mathrm{HPO}_{4}$ ) alone, and phosphorylated in combination with HVED prior or after the chemical modification. Gelatinisation parameters $\left(\mathrm{t}_{0}, \mathrm{t}_{\mathrm{p}}, \mathrm{t}_{\mathrm{e}}\right.$, and $\left.\Delta \mathrm{H}\right)$, paste clarity, FTIR-ATR spectra, as well as contents of amylose, damaged starch, and resistant starch were determined to evaluate the effect of the treatments.

The gelatinisation parameters of native and modified starches are shown in Table 1. Generally, the HVED treatment resulted in a decrease in gelatinisation temperatures (with the exception of endset temperature of maize starch), but the change was not always statistically significant. Similarly, although not always statistically significant, the enthalpy of gelatinisation of the HVED-treated starches was lower compared to that of native ones (except for tapioca starch, where it was higher). This implies that the HVED treatment could cause changes in the morphology of starch granules. Other researchers reported the formation of fissures and cavities [Thirumdas et al., 2017], enlargement of channels, and partial fractioning of starch granules [Bie et al., 2016a]. All these changes facilitate water penetration into the granules and gelatinisation, reflected in decreased gelatinisation temperature and enthalpy. The difference observed for tapioca starch after the HVED treatment regarding gelatinisation enthalpy (Table 1) may be explained by low contents of fat, protein, and ash; a lower content of amylose; and higher molecular weights of amylose and amylopectin compared to all other starches [BeMiller \& Whistler, 2009], which probably makes it less sensitive to granule damage.

Changes in the chemical structure have been reported as a result of plasma treatment as well. Depending on plasma type, treatment conditions, and starch type, depolymerisation, cross-linking, and formation of new functional groups have been reported [Bie et al., 2016b; Khorram et al., 2015]. The HVED treatment applied in this research is not as severe as the plasma treatment in the manner of energy input over time. However, the time was prolonged compared to the plasma treatment (which typically lasts from few seconds to several minutes), and this may have induced a low degree of depolymerisation, as indicated by the reduction in amylose content (Table 2), which, in turn may have contributed to the observed changes in gelatinisation parameters.

Both chemical modifications applied in this research (with $\mathrm{Na}_{5} \mathrm{P}_{3} \mathrm{O}_{10}$ and $\mathrm{Na}_{2} \mathrm{HPO}_{4}$ ) resulted in decreased enthalpy of gelatinisation of most starch types (Table 1). Phosphorylation with $\mathrm{Na}_{2} \mathrm{HPO}_{4}$ had a more pronounced effect, probably because the smaller molecule of this reagent than $\mathrm{Na}_{5} \mathrm{P}_{3} \mathrm{O}_{10}$ penetrated more easily through the active sites of starch. The decrease in gelatinisation enthalpy is typical of substitution reactions, along with a reduced content of resistant starch observed for all analysed samples, and increased paste clarity observed for maize and wheat starch paste (Table 2). Xie \& Shao [2009] also found that mainly starch monoesters were formed over diesters during corn starch phosphorylation.

For most samples, the enthalpy of gelatinisation of the HVED-treated starches before chemical modifications was lower than that of only phosphorylated starches (Table 1). This indicates that starch phosphorylation may have been enhanced by the prior activation of starch molecules through the reaction with free radicals generated in water by HVED [Thirumdas et al., 2018]. However, temperatures of gelatinisation did not follow this trend (Table 1), i.e. the HVED-treated maize starch phosphorylated with $\mathrm{Na}_{2} \mathrm{HPO}_{4}$ had significantly higher gelatinisation temperatures than the one that was only phosphorylated with $\mathrm{Na}_{2} \mathrm{HPO}_{4}$. Since reactions of phosphorylation involve electrically-charged compounds [Sechi \& Marques, 2017], the formation of compounds by starch reaction with free radicals formed by HVED in water does not necessarily imply the activation of a starch granule towards the phosphorylation reaction (the phosphorylation reaction would be enhanced only if the cationic character of starch increases).

When phosphorylated starches were treated with HVED, the enthalpy of gelatinisation was lower compared to both HVED-treated and chemically-modified counterparts with a more pronounced decrease when $\mathrm{Na}_{2} \mathrm{HPO}_{4}$ was used (Table 1). It is apparent that the increase of the anionic character of starch makes it more prone to the reaction with active compounds formed in water by HVED.

Paste clarity is a physical property of starch that is also indicative of its water binding affinity. Substituted starches generally form more clear pastes than native counterparts due to more extensive hydration of granules, while crosslinked starches form more opaque pastes compared to native ones [Bhandari \& Singhal, 2002]. Paste clarity of the investigated starches is shown in Table 2. It is evident that the HVED-treatment resulted in the increase of paste clarity of maize and potato starches, and its decrease for tapioca and wheat starches, although the statistical analysis does not show significance in all cases. The most significant change (decrease) was observed for tapioca starch, and this is consistent with the increase of gelatinisation enthalpy observed for native and HVED-treated tapioca starch (Table 1). Tapioca starch tends to form clearer pastes than cereal starches (which is observed in this research as well) and, unlike potato starch, it has a large number of thin layers of polymers 
TABLE 1. Parameters of gelatinisation of starches modified by high-voltage electrical discharge (HVED), phosphorylation with $\mathrm{Na}_{5} \mathrm{P}_{3} \mathrm{O}_{10}$, and $\mathrm{Na}_{2} \mathrm{HPO}_{4}$, and combination of the processes obtained using differential scanning calorimetry (DSC).

\begin{tabular}{|c|c|c|c|c|c|}
\hline & Modification & $\mathrm{t}_{\mathrm{o}}\left({ }^{\circ} \mathrm{C}\right)$ & $\mathrm{t}_{\mathrm{p}}\left({ }^{\circ} \mathrm{C}\right)$ & $\mathrm{t}_{\mathrm{e}}\left({ }^{\circ} \mathrm{C}\right)$ & $\Delta \mathrm{H}(\mathrm{J} / \mathrm{g})$ \\
\hline \multirow{8}{*}{$\stackrel{\stackrel{N}{\pi}}{\Sigma}$} & Native & $64.90 \pm 0.15^{\mathrm{c}}$ & $70.24 \pm 0.18^{c}$ & $75.06 \pm 0.22^{\mathrm{c}, \mathrm{d}}$ & $12.10 \pm 0.40^{\mathrm{a}}$ \\
\hline & HVED & $64.71 \pm 0.03^{c}$ & $70.13 \pm 0.19^{c}$ & $75.42 \pm 0.18^{c}$ & $11.74 \pm 0.07^{\mathrm{a}, \mathrm{b}}$ \\
\hline & $\mathrm{Na}_{5} \mathrm{P}_{3} \mathrm{O}_{10}$ & $63.32 \pm 0.05^{\mathrm{d}}$ & $69.40 \pm 0.11^{\mathrm{c}, \mathrm{d}}$ & $74.87 \pm 0.18^{\mathrm{d}, \mathrm{e}}$ & $11.19 \pm 0.20^{b, c}$ \\
\hline & $\mathrm{HVED}+\mathrm{Na}_{5} \mathrm{P}_{3} \mathrm{O}_{10}$ & $63.53 \pm 0.28^{\mathrm{d}}$ & $69.19 \pm 0.01^{\mathrm{d}}$ & $74.44 \pm 0.06^{\mathrm{e}}$ & $12.31 \pm 0.03^{\mathrm{a}}$ \\
\hline & $\mathrm{Na}_{5} \mathrm{P}_{3} \mathrm{O}_{10}+\mathrm{HVED}$ & $63.63 \pm 0.16^{\mathrm{d}}$ & $69.16 \pm 0.12^{\mathrm{d}}$ & $74.47 \pm 0.19^{\mathrm{e}}$ & $10.96 \pm 0.43^{\mathrm{c}, \mathrm{d}}$ \\
\hline & $\mathrm{Na}_{2} \mathrm{HPO}_{4}$ & $67.72 \pm 0.13^{\mathrm{a}}$ & $72.52 \pm 0.24^{b}$ & $77.65 \pm 0.02^{\mathrm{b}}$ & $10.92 \pm 0.15^{\mathrm{c}, \mathrm{d}}$ \\
\hline & $\mathrm{HVED}+\mathrm{Na}_{2} \mathrm{HPO}_{4}$ & $69.12 \pm 0.11^{\mathrm{b}}$ & $74.39 \pm 0.02^{\mathrm{a}}$ & $79.19 \pm 0.04^{a}$ & $10.24 \pm 0.08^{\mathrm{d}}$ \\
\hline & $\mathrm{Na}_{2} \mathrm{HPO}_{4}+\mathrm{HVED}$ & $69.12 \pm 0.21^{\mathrm{b}}$ & $74.38 \pm 0.29^{\mathrm{a}}$ & $79.09 \pm 0.49^{\mathrm{a}}$ & $10.25 \pm 0.01^{\mathrm{d}}$ \\
\hline \multirow{8}{*}{$\begin{array}{l}\overrightarrow{\widetilde{J}} \\
\sum_{j}^{5}\end{array}$} & Native & $55.91 \pm 0.13^{\mathrm{C}}$ & $60.33 \pm 0.10^{\mathrm{C}}$ & $64.92 \pm 0.27^{\mathrm{C}}$ & $11.09 \pm 0.17^{\mathrm{A}}$ \\
\hline & HVED & $55.60 \pm 0.01^{\mathrm{C}}$ & $60.03 \pm 0.01^{\mathrm{C}, \mathrm{D}}$ & $64.56 \pm 0.12^{\mathrm{C}}$ & $10.25 \pm 0.18^{\mathrm{B}}$ \\
\hline & $\mathrm{Na}_{5} \mathrm{P}_{3} \mathrm{O}_{10}$ & $55.00 \pm 0.22^{\mathrm{D}}$ & $59.38 \pm 0.14^{\mathrm{D}, \mathrm{E}}$ & $63.84 \pm 0.03^{\mathrm{D}}$ & $9.66 \pm 0.27^{\mathrm{B}, \mathrm{C}}$ \\
\hline & $\mathrm{HVED}+\mathrm{Na}_{5} \mathrm{P}_{3} \mathrm{O}_{10}$ & $54.42 \pm 0.14^{\mathrm{E}}$ & $59.04 \pm 0.33^{\mathrm{E}}$ & $63.20 \pm 0.03^{\mathrm{E}}$ & $9.05 \pm 0.51^{C, D}$ \\
\hline & $\mathrm{Na}_{5} \mathrm{P}_{3} \mathrm{O}_{10}+\mathrm{HVED}$ & $53.97 \pm 0.07^{\mathrm{F}}$ & $58.74 \pm 0.17^{\mathrm{E}}$ & $63.40 \pm 0.07^{\mathrm{D}, \mathrm{E}}$ & $9.46 \pm 0.18^{C}$ \\
\hline & $\mathrm{Na}_{2} \mathrm{HPO}_{4}$ & $58.74 \pm 0.04^{\mathrm{B}}$ & $63.33 \pm 0.01^{\mathrm{B}}$ & $67.82 \pm 0.23^{\mathrm{B}}$ & $9.14 \pm 0.66^{\mathrm{C}, \mathrm{D}}$ \\
\hline & $\mathrm{HVED}+\mathrm{Na}_{2} \mathrm{HPO}_{4}$ & $60.14 \pm 0.07^{\mathrm{A}}$ & $65.16 \pm 0.70^{A}$ & $69.08 \pm 0.09^{\mathrm{A}}$ & $7.90 \pm 0.16^{\mathrm{E}}$ \\
\hline & $\mathrm{Na}_{2} \mathrm{HPO}_{4}+\mathrm{HVED}$ & $59.85 \pm 0.10^{\mathrm{A}}$ & $64.39 \pm 0.04^{\mathrm{A}}$ & $68.87 \pm 0.09^{\mathrm{A}}$ & $8.60 \pm 0.16^{\mathrm{D}, \mathrm{E}}$ \\
\hline \multirow{8}{*}{$\begin{array}{l}\frac{0}{\pi} \\
\frac{\pi}{0} \\
2\end{array}$} & Native & $57.23 \pm 0.21^{\mathrm{i}}$ & $63.12 \pm 2.07^{\mathrm{i}}$ & $66.33 \pm 0.08^{i}$ & $18.68 \pm 0.15^{\mathrm{i}}$ \\
\hline & HVED & $56.96 \pm 0.14^{i}$ & $61.35 \pm 0.31^{\mathrm{ii}}$ & $66.36 \pm 0.48^{\mathrm{i}}$ & $17.88 \pm 0.36^{\mathrm{ii}}$ \\
\hline & $\mathrm{Na}_{5} \mathrm{P}_{3} \mathrm{O}_{10}$ & $52.71 \pm 0.05^{\mathrm{iii}}$ & $57.17 \pm 0.09^{v}$ & $62.15 \pm 0.06^{\text {iv }}$ & $15.53 \pm 0.62^{\mathrm{iii}}$ \\
\hline & $\mathrm{HVED}+\mathrm{Na}_{5} \mathrm{P}_{3} \mathrm{O}_{10}$ & $52.66 \pm 0.23^{\mathrm{iii}}$ & $57.09 \pm 0.01^{v}$ & $62.15 \pm 0.37^{\mathrm{iv}}$ & $15.15 \pm 0.19^{\mathrm{iii}}$ \\
\hline & $\mathrm{Na}_{5} \mathrm{P}_{3} \mathrm{O}_{10}+\mathrm{HVED}$ & $51.96 \pm 0.08^{\mathrm{iv}}$ & $56.62 \pm 0.07^{\mathrm{v}}$ & $61.75 \pm 0.08^{\text {iv }}$ & $15.51 \pm 0.67^{\mathrm{iii}}$ \\
\hline & $\mathrm{Na}_{2} \mathrm{HPO}_{4}$ & $52.77 \pm 0.14^{\mathrm{iii}}$ & $58.10 \pm 0.21^{\mathrm{iv}}$ & $63.51 \pm 0.14^{\mathrm{iii}}$ & $14.04 \pm 0.51^{\text {iv }}$ \\
\hline & $\mathrm{HVED}+\mathrm{Na}_{2} \mathrm{HPO}_{4}$ & $54.10 \pm 0.01^{\mathrm{ii}}$ & $59.42 \pm 0.01^{\mathrm{iii}}$ & $64.57 \pm 0.04^{\mathrm{ii}}$ & $12.95 \pm 0.02^{\mathrm{v}}$ \\
\hline & $\mathrm{Na}_{2} \mathrm{HPO}_{4}+\mathrm{HVED}$ & $54.10 \pm 0.22^{\mathrm{ii}}$ & $59.43 \pm 0.05^{\mathrm{iii}}$ & $64.79 \pm 0.24^{\mathrm{ii}}$ & $13.36 \pm 0.36^{\mathrm{iv}, \mathrm{v}}$ \\
\hline \multirow{8}{*}{ 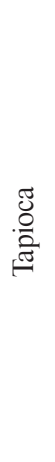 } & Native & $63.48 \pm 0.30^{\mathrm{III}}$ & $69.74 \pm 0.12^{\mathrm{II}}$ & $77.82 \pm 0.04^{\mathrm{II}}$ & $10.55 \pm 0.64^{\mathrm{v}}$ \\
\hline & HVED & $61.56 \pm 0.18^{\mathrm{IV}}$ & $67.25 \pm 0.40^{\mathrm{III}}$ & $75.17 \pm 0.14^{\mathrm{IV}}$ & $15.19 \pm 0.29^{I}$ \\
\hline & $\mathrm{Na}_{5} \mathrm{P}_{3} \mathrm{O}_{10}$ & $59.85 \pm 0.06^{V}$ & $66.04 \pm 0.05^{\mathrm{IV}}$ & $73.19 \pm 0.12^{\mathrm{V}}$ & $14.72 \pm 0.30^{\mathrm{I}}$ II \\
\hline & $\mathrm{HVED}+\mathrm{Na}_{5} \mathrm{P}_{3} \mathrm{O}_{10}$ & $59.96 \pm 0.02^{\mathrm{V}}$ & $65.88 \pm 0.04^{\mathrm{IV}}$ & $73.03 \pm 0.20^{\mathrm{V}}$ & $14.15 \pm 0.47^{\mathrm{II}}$ \\
\hline & $\mathrm{Na}_{5} \mathrm{P}_{3} \mathrm{O}_{10}+\mathrm{HVED}$ & $59.73 \pm 0.01^{\mathrm{V}}$ & $65.83 \pm 0.11^{\mathrm{IV}}$ & $73.24 \pm 0.23^{\mathrm{V}}$ & $14.47 \pm 0.19^{\mathrm{IV}}$ \\
\hline & $\mathrm{Na}_{2} \mathrm{HPO}_{4}$ & $64.29 \pm 0.02^{\mathrm{II}}$ & $70.20 \pm 0.02^{\mathrm{II}}$ & $77.16 \pm 0.01^{\mathrm{III}}$ & $13.29 \pm 0.17^{\mathrm{III}}$ \\
\hline & $\mathrm{HVED}+\mathrm{Na}_{2} \mathrm{HPO}_{4}$ & $66.01 \pm 0.29^{1}$ & $71.83 \pm 0.62^{\mathrm{I}}$ & $78.70 \pm 0.64^{\mathrm{I}}$ & $12.13 \pm 0.41^{\mathrm{IV}}$ \\
\hline & $\mathrm{Na}_{2} \mathrm{HPO}_{4}+\mathrm{HVED}$ & $65.77 \pm 0.21^{\mathrm{I}}$ & $71.76 \pm 0.07^{1}$ & $78.77 \pm 0.14^{\mathrm{I}}$ & $12.03 \pm 0.47^{\mathrm{IV}}$ \\
\hline
\end{tabular}

$t_{0}$, onset temperature; $t_{p}$, peak temperature; $t_{e}$, endset temperature; $\Delta H$, enthalpy of gelatinisation. The results are expressed as mean \pm standard deviation $(n=3)$. Values with different superscripts in the same column are different for the same starch type $(\mathrm{p}<0.05)$.

[Banura et al., 2018]. This may be the reason for the unique effect of HVED on its clarity. However, Banura et al. [2018] reported that plasma treatment increased the swelling capacity of both maize and tapioca starches, which would imply that clarity should also increase. In turn, Bie et al. [2016a] reported that glow plasmas broke the hydrogen bonding network at the molecular level of tapioca starch and change starch crystallites. Unlike these researches, results obtained in the present study (increased enthalpy of gelatinisation, reduced paste clarity) imply that HVED, unlike plasma treatment, causes better alignment of starch chains and more ordered structural organisation of tapioca starch polymers. 
TABLE 2. Paste clarity, contents of amylose, damaged starch, and resistant starch of starches modified by high-voltage electrical discharge (HVED) treatment, phosphorylation with $\mathrm{Na}_{5} \mathrm{P}_{3} \mathrm{O}_{10}$, and $\mathrm{Na}_{2} \mathrm{HPO}_{4}$, and combination of the processes.

\begin{tabular}{|c|c|c|c|c|c|}
\hline & Modification & Paste clarity $(\% \mathrm{~T})$ & Amylose $(\%)$ & Damaged starch (\%) & Resistant starch (g/100 g d.m.) \\
\hline \multirow{8}{*}{$\stackrel{\stackrel{\tilde{N}}{\tilde{J}}}{\sum}$} & Native & $8.31 \pm 0.28^{\mathrm{d}}$ & $15.80 \pm 0.05^{\mathrm{a}}$ & $2.41 \pm 0.08^{\mathrm{a}}$ & $2.40 \pm 0.54^{\mathrm{a}}$ \\
\hline & HVED & $8.97 \pm 0.16^{\mathrm{d}}$ & $15.20 \pm 0.06^{\mathrm{a}}$ & $0.98 \pm 0.04^{\mathrm{b}}$ & $2.06 \pm 0.34^{\mathrm{a}, \mathrm{b}}$ \\
\hline & $\mathrm{Na}_{5} \mathrm{P}_{3} \mathrm{O}_{10}$ & $18.90 \pm 0.42^{\mathrm{a}}$ & $14.19 \pm 0.11^{\mathrm{b}}$ & $0.82 \pm 0.01^{\mathrm{d}}$ & $1.04 \pm 0.89^{\mathrm{a}, \mathrm{b}}$ \\
\hline & $\mathrm{HVED}+\mathrm{Na}_{5} \mathrm{P}_{3} \mathrm{O}_{10}$ & $13.15 \pm 0.21^{\mathrm{c}}$ & $13.88 \pm 0.14^{\mathrm{b}, \mathrm{c}}$ & $1.02 \pm 0.04^{\mathrm{b}}$ & $0.80 \pm 0.19^{\mathrm{a}, \mathrm{b}}$ \\
\hline & $\mathrm{Na}_{5} \mathrm{P}_{3} \mathrm{O}_{10}+\mathrm{HVED}$ & $16.15 \pm 0.07^{\mathrm{b}}$ & $12.54 \pm 0.18^{\mathrm{d}}$ & $0.89 \pm 0.00^{c}$ & $1.48 \pm 0.53^{\mathrm{a}, \mathrm{b}}$ \\
\hline & $\mathrm{Na}_{2} \mathrm{HPO}_{4}$ & $9.94 \pm 0.03^{\mathrm{d}}$ & $13.15 \pm 0.62^{\mathrm{d}}$ & $0.86 \pm 0.03^{\mathrm{c}, \mathrm{d}}$ & $0.59 \pm 0.06^{\mathrm{b}}$ \\
\hline & $\mathrm{HVED}+\mathrm{Na}_{2} \mathrm{HPO}_{4}$ & $8.73 \pm 0.06^{\mathrm{d}}$ & $13.50 \pm 0.57^{\mathrm{b}, \mathrm{c}}$ & $0.68 \pm 0.02^{\mathrm{e}}$ & $0.52 \pm 0.16^{\mathrm{b}}$ \\
\hline & $\mathrm{Na}_{2} \mathrm{HPO}_{4}+\mathrm{HVED}$ & $9.43 \pm 0.01^{\mathrm{d}}$ & $15.75 \pm 0.33^{\mathrm{a}}$ & $0.54 \pm 0.00^{\mathrm{f}}$ & $0.50 \pm 0.01^{\mathrm{b}}$ \\
\hline \multirow{8}{*}{$\begin{array}{l}\vec{\Xi} \\
\sum_{\vec{J}}^{E}\end{array}$} & Native & $8.60 \pm 0.03^{\mathrm{C}}$ & $20.27 \pm 0.32^{\mathrm{A}}$ & $0.64 \pm 0.01^{\mathrm{C}}$ & $0.66 \pm 0.01^{\mathrm{A}}$ \\
\hline & HVED & $7.66 \pm 0.19^{\mathrm{C}}$ & $17.03 \pm 0.93^{\mathrm{D}}$ & $0.67 \pm 0.06^{\mathrm{C}}$ & $0.22 \pm 0.01^{\mathrm{A}}$ \\
\hline & $\mathrm{Na}_{5} \mathrm{P}_{3} \mathrm{O}_{10}$ & $17.50 \pm 0.42^{\mathrm{A}}$ & $18.12 \pm 0.02^{\mathrm{B}, \mathrm{C}}$ & $0.83 \pm 0.05^{\mathrm{A}}$ & $0.29 \pm 0.02^{\mathrm{A}}$ \\
\hline & $\mathrm{HVED}+\mathrm{Na}_{5} \mathrm{P}_{3} \mathrm{O}_{10}$ & $11.45 \pm 0.64^{\mathrm{B}}$ & $17.96 \pm 0.15^{\mathrm{C}, \mathrm{D}}$ & $0.75 \pm 0.01^{\mathrm{B}}$ & $0.29 \pm 0.17^{\mathrm{A}}$ \\
\hline & $\mathrm{Na}_{5} \mathrm{P}_{3} \mathrm{O}_{10}+\mathrm{HVED}$ & $11.90 \pm 0.28^{\mathrm{B}}$ & $20.73 \pm 0.91^{\mathrm{A}}$ & $0.75 \pm 0.04^{\mathrm{B}}$ & $0.18 \pm 0.01^{\mathrm{A}}$ \\
\hline & $\mathrm{Na}_{2} \mathrm{HPO}_{4}$ & $12.75 \pm 0.07^{\mathrm{B}}$ & $19.04 \pm 0.01^{\mathrm{B}}$ & $0.45 \pm 0.00^{\mathrm{D}}$ & $0.15 \pm 0.03^{\mathrm{A}}$ \\
\hline & $\mathrm{HVED}+\mathrm{Na}_{2} \mathrm{HPO}_{4}$ & $11.70 \pm 0.00^{\mathrm{B}}$ & $16.03 \pm 0.21^{\mathrm{E}}$ & $0.35 \pm 0.02^{\mathrm{E}}$ & $0.17 \pm 0.00^{\mathrm{A}}$ \\
\hline & $\mathrm{Na}_{2} \mathrm{HPO}_{4}+\mathrm{HVED}$ & $12.35 \pm 0.35^{\text {B }}$ & $17.52 \pm 0.52^{\mathrm{C}, \mathrm{D}}$ & $0.37 \pm 0.04^{\mathrm{E}}$ & $0.16 \pm 0.01^{\mathrm{A}}$ \\
\hline \multirow{8}{*}{$\begin{array}{l}\frac{0}{0} \\
\text { 范 } \\
2\end{array}$} & Native & $87.10 \pm 0.57^{\mathrm{ii}}$ & $14.14 \pm 1.54^{\mathrm{i}}$ & $1.89 \pm 0.02^{\mathrm{i}}$ & $69.50 \pm 3.09^{i}$ \\
\hline & HVED & $91.15 \pm 0.35^{\mathrm{i}}$ & $11.87 \pm 0.16^{\mathrm{ii}}$ & $0.35 \pm 0.02^{\mathrm{iii}}$ & $69.39 \pm 0.00^{\mathrm{i}}$ \\
\hline & $\mathrm{Na}_{5} \mathrm{P}_{3} \mathrm{O}_{10}$ & $63.15 \pm 0.92^{\mathrm{ii}}$ & $11.77 \pm 0.10^{\mathrm{ii}}$ & $0.42 \pm 0.03^{\mathrm{ii}}$ & $34.32 \pm 0.99^{v}$ \\
\hline & $\mathrm{HVED}+\mathrm{Na}_{5} \mathrm{P}_{3} \mathrm{O}_{10}$ & $82.00 \pm 3.25^{\mathrm{iii}}$ & $9.73 \pm 0.25^{\mathrm{iii}}$ & $0.25 \pm 0.02^{\mathrm{iv}, \mathrm{v}}$ & $46.52 \pm 0.39^{\mathrm{ii}}$ \\
\hline & $\mathrm{Na}_{5} \mathrm{P}_{3} \mathrm{O}_{10}+\mathrm{HVED}$ & $77.90 \pm 0.99^{\mathrm{iv}}$ & $9.45 \pm 0.18^{\mathrm{iii}}$ & $0.42 \pm 0.03^{\mathrm{ii}}$ & $38.24 \pm 1.29^{\mathrm{iv}}$ \\
\hline & $\mathrm{Na}_{2} \mathrm{HPO}_{4}$ & $28.20 \pm 0.28^{\mathrm{iv}}$ & $11.63 \pm 0.71^{\mathrm{ii}}$ & $0.41 \pm 0.01^{\mathrm{ii}}$ & $47.44 \pm 1.77^{\mathrm{ii}}$ \\
\hline & $\mathrm{HVED}+\mathrm{Na}_{2} \mathrm{HPO}_{4}$ & $23.90 \pm 0.14^{\mathrm{vii}}$ & $11.66 \pm 0.02^{\mathrm{ii}}$ & $0.22 \pm 0.01^{\mathrm{v}}$ & $41.57 \pm 0.04^{\mathrm{iii}}$ \\
\hline & $\mathrm{Na}_{2} \mathrm{HPO}_{4}+\mathrm{HVED}$ & $24.05 \pm 0.35^{\text {vii }}$ & $12.05 \pm 0.20^{\mathrm{ii}}$ & $0.29 \pm 0.02^{\mathrm{iv}}$ & $4.48 \pm 0.08^{\mathrm{vi}}$ \\
\hline \multirow{8}{*}{ 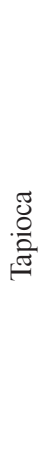 } & Native & $48.85 \pm 0.35^{\mathrm{I}}$ & $12.85 \pm 0.36^{\mathrm{I}}$ & $0.02 \pm 0.00^{\mathrm{V}}$ & $15.15 \pm 0.10^{1}$ \\
\hline & HVED & $40.40 \pm 1.70^{\mathrm{II}}$ & $10.73 \pm 0.13^{\mathrm{II}, \mathrm{III}}$ & $0.01 \pm 0.00^{\mathrm{V}}$ & $5.42 \pm 0.57^{\mathrm{IV}}$ \\
\hline & $\mathrm{Na}_{5} \mathrm{P}_{3} \mathrm{O}_{10}$ & $38.20 \pm 0.57^{\mathrm{IV}}$ & $7.29 \pm 0.10^{\mathrm{IV}}$ & $0.18 \pm 0.00^{\text {II }}$ & $3.16 \pm 2.26^{\mathrm{v}}$ \\
\hline & $\mathrm{HVED}+\mathrm{Na}_{5} \mathrm{P}_{3} \mathrm{O}_{10}$ & $40.15 \pm 0.21^{\mathrm{III}}$ & $10.06 \pm 0.33^{\mathrm{III}}$ & $0.34 \pm 0.03^{\mathrm{I}}$ & $11.30 \pm 0.12^{\mathrm{II}}$ \\
\hline & $\mathrm{Na}_{5} \mathrm{P}_{3} \mathrm{O}_{10}+\mathrm{HVED}$ & $44.00 \pm 0.99^{\text {II }}$ & $10.99 \pm 0.00^{\mathrm{III}}$ & $0.29 \pm 0.01^{\mathrm{I}}$ & $2.81 \pm 0.59^{\mathrm{v}}$ \\
\hline & $\mathrm{Na}_{2} \mathrm{HPO}_{4}$ & $26.95 \pm 0.49^{v}$ & $10.17 \pm 0.04^{I I, I I I}$ & $0.13 \pm 0.01^{\mathrm{II}, \mathrm{III}}$ & $3.32 \pm 0.05^{\mathrm{V}}$ \\
\hline & $\mathrm{HVED}+\mathrm{Na}_{2} \mathrm{HPO}_{4}$ & $27.65 \pm 0.35^{\mathrm{v}}$ & $10.19 \pm 0.11^{\mathrm{IIIIII}}$ & $0.09 \pm 0.01^{\mathrm{II}, \mathrm{III}}$ & $9.97 \pm 0.06^{\mathrm{II}, \mathrm{III}}$ \\
\hline & $\mathrm{Na}_{2} \mathrm{HPO}_{4}+\mathrm{HVED}$ & $28.80 \pm 0.85^{\vee}$ & $11.52 \pm 0.54^{\mathrm{II}}$ & $0.04 \pm 0.01^{1 \mathrm{IVV}}$ & $9.54 \pm 0.00^{\mathrm{III}}$ \\
\hline
\end{tabular}

$\% \mathrm{~T}$, transmittance of $1 \%$ starch suspension measured at $650 \mathrm{~nm}$ against distilled water. The results are expressed as mean \pm standard deviation $(\mathrm{n}=3)$. Values with different superscripts in the same column are different for the same starch type $(\mathrm{p}<0.05)$.

Generally, phosphorylation induced an increase of paste clarity of the investigated cereal starches, and a decrease of this property for tuber starches, as shown in Table 2. Here, a more pronounced effect on the increase of paste clarity in tuber starches was observed for starches phosphorylated with $\mathrm{Na}_{5} \mathrm{P}_{3} \mathrm{O}_{10}$, than with $\mathrm{Na}_{2} \mathrm{HPO}_{4}$, probably due to larger mol- ecules which keep starch chains more spaced and make light passing easier. Tuber starches, like potato and tapioca ones, are characterised by larger granules and a higher degree of polymerisation of amylose than maize and wheat starches [Banura et al., 2018], which may be the reason for the observed opposite trend in paste clarity. 

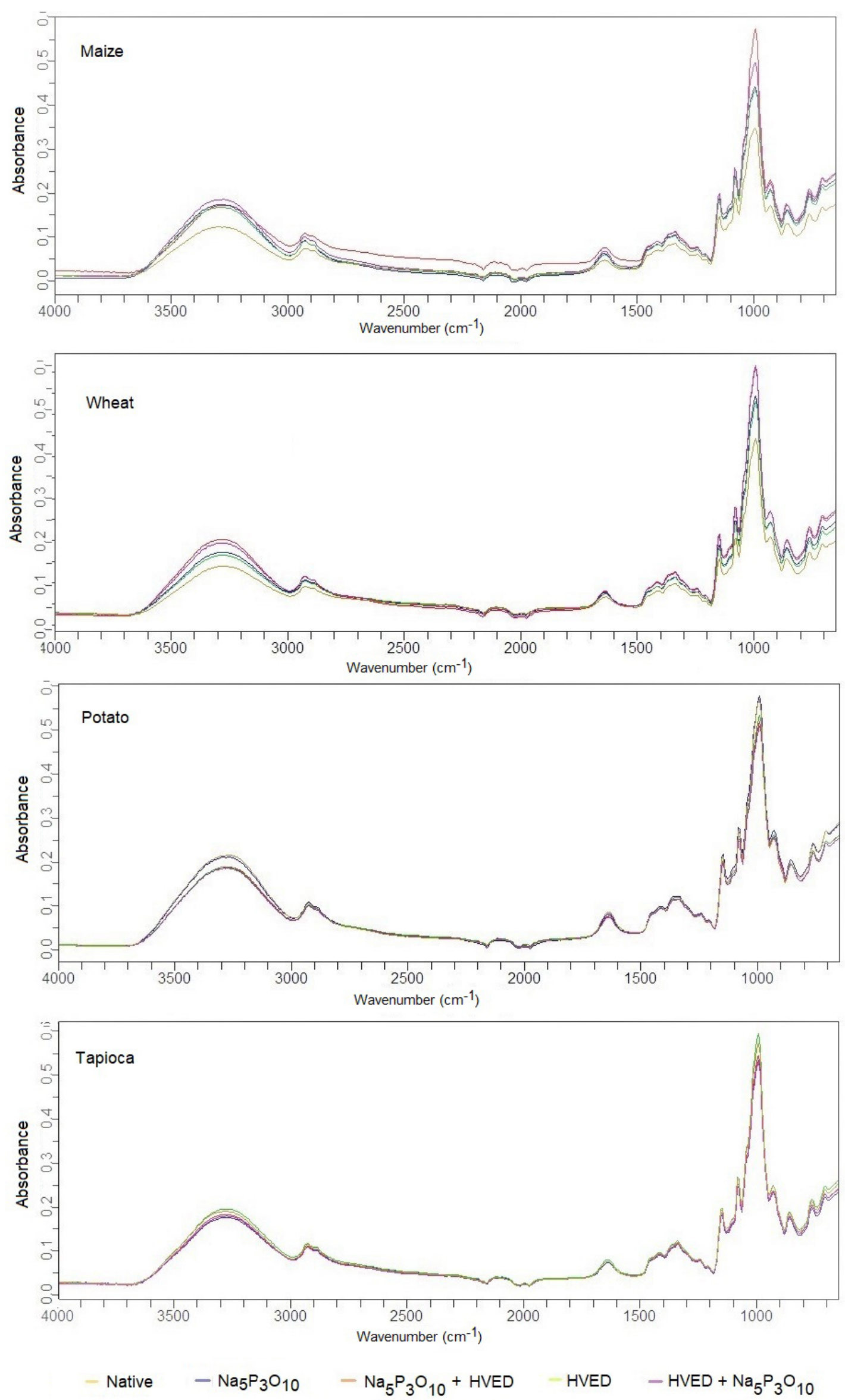

FIGURE 1. Fourier-transform infrared spectroscopy-attenuated total reflectance (FTIR-ATR) spectra of starches modified with $\mathrm{Na}_{5} \mathrm{P}_{3} \mathrm{O}_{10}$, with and without high-voltage electrical discharge (HVED) treatment. 

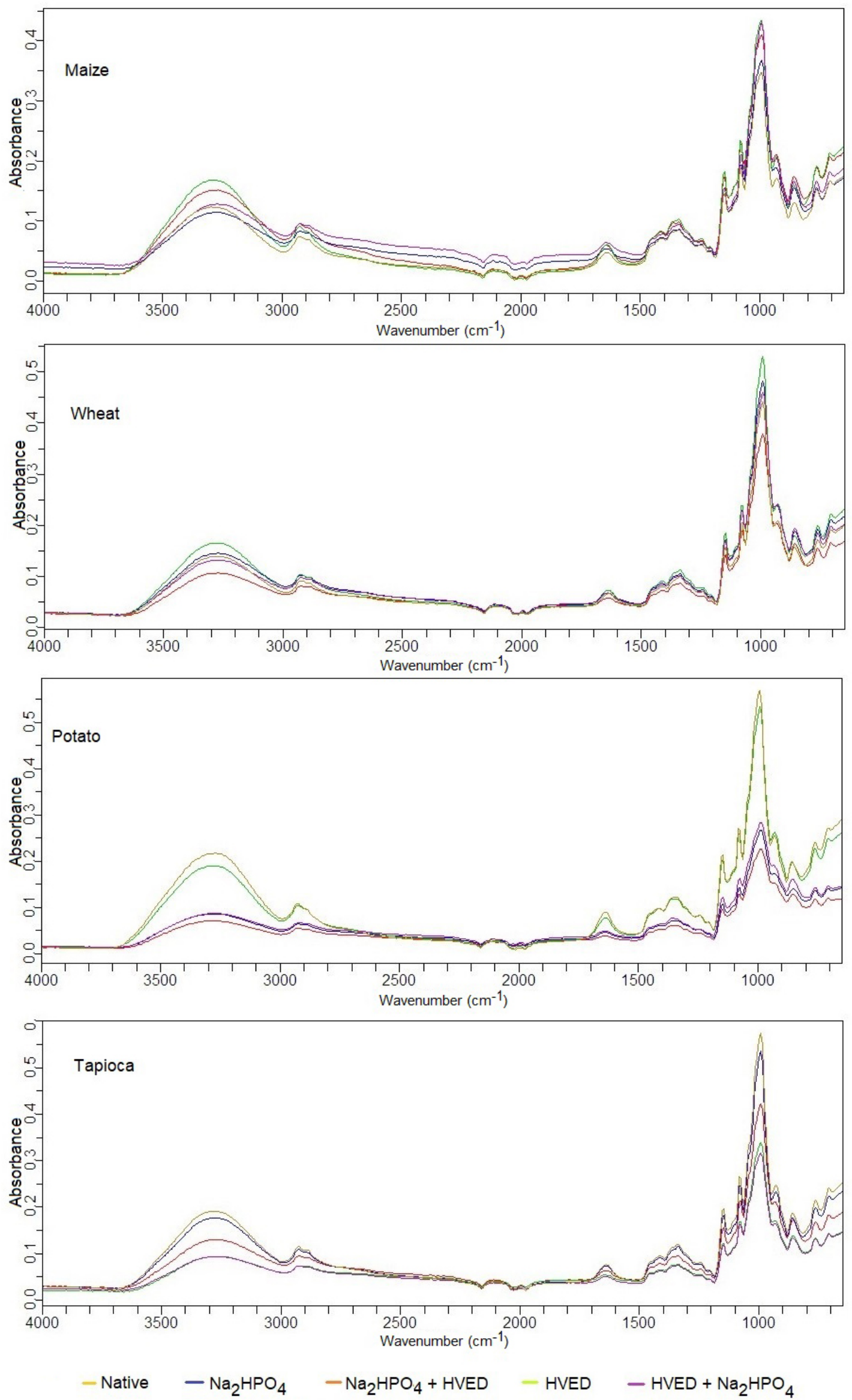

FIGURE 2. Fourier-transform infrared spectroscopy-attenuated total reflectance (FTIR-ATR) spectra of starches modified with $\mathrm{Na}_{2} \mathrm{HPO}_{4}$, with and without high-voltage electrical discharge (HVED) treatment. 
The HVED treatment before phosphorylation resulted in a reduced paste clarity compared to the phosphorylated counterpart of cereal starches. Although statistical difference was not observed for wheat starch, the values are indeed lower $(11.45 \% \mathrm{~T}$ compared to $12.75 \% \mathrm{~T})$ for this sample as well. Again, for tuber starches the trend was opposite, i.e., only the HVED-treated potato starch modified with $\mathrm{Na}_{2} \mathrm{HPO}_{4}$ revealed lower pasted clarity than the phosphorylated counterpart (Table 2). Generally, for cereal starches, paste clarity followed the order: HVED-treated starch < HVED-treated + phosphorylated < phosphorylated starch; and for tuber starches it followed the order: phosphorylated < HVED-treated + phosphorylated < HVED-treated starch. When HVED was applied after the phosphorylation, the clarity of pastes made of cereal starches decreased in the following order: phosphorylated $>$ phosphorylated + HVED treated $>$ HVED treated starch, while the clarity of pastes made of tuber starches did not show any trend.

Chaiwat et al. [2016] stated that variations in paste clarity of starch after HVED treatment depended on the final outcome of two competing reactions: cross-linking and depolymerisation. Cross-linking produces a more ordered structure and prevents the dissociation of starch chains during pasting, while depolymerisation increases paste clarity.

Amylose content in all analysed starches decreased after HVED treatment (Table 2) (although, the differences were not always statistically significant), which is consistent with results reported for plasma-treated starch [Bie et al., 2016b; Thirumdas et al., 2018]. Thirumdas et al. [2018] ascribed this phenomenon to the depolymerisation of amylose, since physical modification predominantly affects amorphous regions of starch granules [Ascheri et al., 2014]. In this research, a decrease in amylose content was observed after phosphorylation as well (Table 2). Ascheri et al. [2014] also reported decreased amylose content after phosphorylation of $S$. lycocarpum starch. In most samples treated by a combination of HVED and phosphorylation, the amylose contents were also lower compared to native starches (Table 2). However, it is difficult to reveal any trend regarding the coupled use of these methods. Starch damage was smaller after all modifications, except for tapioca starch, where virtually no damaged starch was present in native starch, and for wheat starch modified with $\mathrm{Na}_{5} \mathrm{P}_{3} \mathrm{O}_{10}$ alone and in combination with HVED. Since damaged starch is a portion of starch that is physically broken or fragmented, and therefore has more affinity to water [Tian \& Sun, 2020], it is possible that damaged starch was simply washed out during modification reactions.

Changes in the chemical nature of starches due to the HVED treatment and phosphorylation, both alone and in combination, are further supported by a reduction in resistant starch content determined in most samples ( $\mathrm{Ta}-$ ble 2). Although the resistant starch content is typically linked to a higher amylose content (commonly high-amylose starches are used to produce resistant starch) [Liu et al., 2020] and resistance to gelatinisation (temperatures and enthalpy of gelatinisation) [Apostolidis \& Mandala, 2020], this research showed no obvious correlation between these parameters (results not shown). Furthermore, FTIR-ATR spectra (Figures 1 and 2) revealed that the number of $-\mathrm{OH}$ groups increased, which is visible from the increase in the heights of peaks at $993 \mathrm{~cm}^{-1}$ (C-O-H bending vibrations) and $3440 \mathrm{~cm}^{-1}$ (O-H stretching vibrations) [Deeyai et al., 2013; Guntzler \& Gremlich, 2006]. This implies that starch depolymerisation was the dominant reaction during the HVED treatment. However, a band at around $1000 \mathrm{~cm}^{-1}$ is also used as an indicator of crystallinity [Deeyai et al., 2013]. The higher peak at $1000 \mathrm{~cm}^{-1}$ for modified starches would show that the crystalline order of starch granules was increased after all modifications, especially in the case of maize and wheat starches (Figures 1 and 2). Capron et al. [2007] reported that most authors use bands at 1047 and $1022 \mathrm{~cm}^{-1}$ to evaluate crystalline order of starch and link the band at $1000 \mathrm{~cm}^{-1}$ to intramolecular hydrogen bonds of hydroxyl groups, which "could allow inter-double helices associations", and concluded that the band at $1000 \mathrm{~cm}^{-1}$ was the result of hydrated crystalline regions. Since bands corresponding to phosphorus-containing groups of starches overlap with bands associated with C-O stretching vibrations of the glycosidic bond $\left(1085 \mathrm{~cm}^{-1}\right)$, pyranose ring vibrations (929 $\left.\mathrm{cm}^{-1}\right)$ [Deeyai et al., 2013; Delval et al., 2004], and the band showing the crystalline order of starch (around $1000 \mathrm{~cm}^{-1}$ ) [Ispas-Szabo et al., 1999], it is hard to confirm by FTIR-ATR that -OH groups were indeed substituted.

\section{CONCLUSIONS}

The HVED treatment of starch in an aqueous suspension may be used as an effective tool to modify starch properties both as a single method and in combination with its phosphorylation. As a result of the HVED treatment, generally, a reduction was observed in gelatinisation enthalpy, amylose content, and resistant starch content. The magnitude of these changes significantly depended on starch type. The HVED treatment prior to phosphorylation resulted in more pronounced changes of the investigated properties compared to phosphorylation alone, indicating that electrical discharges in water activate starch molecules, facilitate penetration of water to starch, and make them more prone to the reaction with phosphorylation agents. Additional examination of starch properties, such as swelling power, solubility, pasting properties, colour, morphology of starch granules, texture properties. etc. is, however, needed to get a better insight of the applicability of such modified starch in the food industry.

\section{RESEARCH FUNDING}

This research was funded in part by Josip Juraj Strossmayer University of Osijek, under the research project "Application of gas plasma and ultrasound in starch modification processes" and as part of the "Atrium of Knowledge" project co-financed by the European Union from the European Regional Development Fund and the Operational Programme Competitiveness and Cohesion 2014-2020.

\section{CONFLICTS OF INTEREST}

The authors declare no conflict of interest. The funders had no role in the design of the study; in the collection, analyses, or interpretation of data; in the writing of the manuscript, or in the decision to publish the results. 


\section{ORCID IDs}

Đ. Ačkar https://orcid.org/0000-0003-4257-2907

J. Babić https://orcid.org/0000-0002-6453-1850

M. Grec https://orcid.org/0000-0003-0915-2767

I. Grgić https://orcid.org/0000-0001-5166-1579

A. Gryszkin https://orcid.org/0000-0001-6139-0098

A. Jozinović https://orcid.org/0000-0001-9627-1013

M. Kopjar https://orcid.org/0000-0001-6864-4652

B. Miličević https://orcid.org/0000-0002-9680-6353

S. Zavadlav https://orcid.org/0000-0002-1163-1452

T. Zięba https://orcid.org/0000-0002-2791-342X

\section{REFERENCES}

1. AACC Method 76-31.01. (2010). Determination of Damaged Starch - Spectrophotometric Method. AACC International Approved Methods of Analysis 11th edition. American Association of Cereal Chemists, St. Paul, Minnesota, USA.

2. Ačkar, Đ., Babić, J., Šubarić, D., Kopjar, M., Miličević, B. (2010). Isolation of starch from two wheat varieties and their modification with epichlorohydrin. Carbohydrate Polymers, 81 (1), 76-82. https://doi.org/10.1016/j.carbpol.2010.01.058

3. AOAC Method 2002.02. (2005). Resistant starch in starch and plant materials. Official Methods of Analysis of the AOAC International 18th edition. Association of Official Analytical Chemists, Gaithersburg, Maryland, USA.

4. Apostolidis, E., Mandala, I. (2020). Modification of resistant starch nanoparticles using high-pressure homogenization treatment. Food Hydrocolloids, 103, art. no. 105677.

https://doi.org/10.1016/j.foodhyd.2020.105677

5. Ascheri, D.P.R., Pereira, L.D., Bastos, S.M.C. (2014). Chemical, morphological, rheological and thermal properties of Solanum lycocarpum phosphorylated starches. Revista Ceres Vicosa, 61 (4), 458-466.

https://doi.org/10.1590/0034-737X201461040003

6. Banura, S., Thirumdas, R., Kaur, A., Deshmukh, R.R., Annapure, S. (2018). Modification of starch using low pressure radio frequency air plasma. LWT - Food Science \& Technology, 89, 719-724. https://doi.org/10.1016/j.Iwt.2017.11.056

7. Barišić, V., Flanjak, I., Križić, I., Jozinović, A., Šubarić, D., Babić, J., Miličević, B., Ačkar, Đ. (2020). Impact of high-voltage electric discharge treatment on cocoa shell phenolic components and methylxanthines. Journal of Food Process Engineering, 43(1), art. no. e13057.

https://doi.org/10.1111/jfpe.13057

8. BeMiller, J., Whistler, R. (Eds.) (2009). Starch Chemistry and Technology 3rd edition. Academic Press, Burlington, Massachusetts, USA. pp. 149-236, 373-568, 629-656.

https://doi.org/10.1016/S1082-0132(08)X0009-3

9. Bhandari, P.N., Singhal, R.S. (2002). Effect of succinylation on the corn and amaranth starch pastes - review. Carbohydrate Polymers, 48(3), 233-240.

https://doi.org/10.1016/S0144-8617(01)00310-1

10. Bie, P., Li, X., Xie, F., Chen, L., Zhang, B., Li, L. (2016a). Supramolecular structure and thermal behaviour of cassava starch treated by oxygen and helium glow-plasmas. Innovative Food Science and Emerging Technologies, 34, 336-343.

https://doi.org/10.1016/j.ifset.2016.03.005
11. Bie, P., Pu, H., Zhang, B., Su, J., Chen, L., Li, X. (2016b). Structural characteristics and rheological properties of plasma-treated starch. Innovative Food Science and Emerging Technologies, 34, 196-204.

https://doi.org/10.1016/j.ifset.2015.11.019

12. Capron, I., Robert, P., Colonna, P., Brogly, M., Planchot, V. (2007). Starch in rubbery and glassy states by FTIR spectroscopy. Carbohydrate Polymers, 68(2), 249-259. https://doi. org/10.1016/j.carbpol.2006.12.015

13. Chaiwat, W., Wongsagonsup, R., Tangpanichyannon, N., Jariyaporn, T., Deeyai, P., Suphantharika, M., Fuongfuchat, A., Nisoa, M., Dangtip, S. (2016). Argon plasma treatment of tapioca starch using a semi-continuous Downer reactor. Food and Bioprocess Technology, 9, 1125-1134.

https://doi.org/10.1007/s11947-016-1701-6

14. Deeyai, P., Suphantharika, M., Wongsagonsup, R., Dangtip, S. (2013). Characterization of modified tapioca starch in atmospheric argon plasma under diverse humidity by FTIR spectroscopy. Chinese Physics Letters, 30(1), art. no. 018103.

https://doi.org/10.1088/0256-307X/30/1/018103

15. Delval, F., Crini, G., Bertini, S., Morin-Crini, N., Badot, P-M., Vebrel, J., Torri, G. (2004). Characterization of crosslinked starch materials with spectroscopic techniques. Journal of Applied Polymer Science, 93(6), 2650-2663.

https://doi.org/10.1002/app.20851

16. Gibson, T.S., Solah, V.A., McCleary, B.V. (1997). A procedure to measure amylose in cereal starches and flours with concanavalin A. Journal of Cereal Science, 25(2), 111-119.

https://doi.org/10.1006/jcrs.1996.0086

17. Guntzler, H., Gremlich, H.-U. (2006). Uvod u infracrvenu spektroskopiju. Školska knjiga, Zagreb, Croatia. pp. 129-210 (Title in English: IR-Spectroscopy: An Introduction. Publisher in English language: Wiley-VCH).

18. Ispas-Szabo, P., Ravenelle, F., Hassan, I., Preda, M., Mateescu, M.A. (1999). Structure - properties relationship in cross-linked high-amylose starch for use in controlled drug release. Carbohydrate Research, 323(1-4), 163-175.

https://doi.org/10.1016/S0008-6215(99)00250-5

19. Khorram, S., Zakerhamidi, M.S., Karimzadeh, Z. (2015). Polarity functions' characterization and the mechanism of starch modification by DC glow discharge plasma. Carbohydrate Polymers, 127, 72-78.

https://doi.org/10.1016/j.carbpol.2015.03.056

20. Lim, S., Seib, P.A. (1993). Preparation and pasting properties of wheat and corn starch phosphates. Cereal Chemistry, 70(2), 137-144.

21. Liu, Y., Liu, J., Kong, J., Wang, R., Liu, M., Strappe, P., Blanchard, C., Zhou, Z. (2020). Citrate esterification of debranched waxy maize starch: structural, physicochemical and amylolysis properties. Food Hydrocolloids, 104, art. no. 105704.

https://doi.org/10.1016/j.foodhyd.2020.105704

22. Prasanthi, N.L., Rama Rao, N. (2010). Starch Phosphate: A novel pharmaceutical excipient for tablet formulation. Journal of Pharmacy Research, 3(12), 2919-2923.

23. Raina, C.S., Singh, S., Bawa, A.S., Saxena, D.C. (2006). Some characteristics of acetylated, cross-linked and dual-modified Indian rice starches. European Food Research and Technology, 223, $561-570$.

https://doi.org/10.1007/s00217-005-0239-z 
24. Rosello-Soto, E., Barba, F.J., Parniakov, O., Galanakis, C.M., Lebovka, N., Grimi, N., Vorobiev, E. (2015). High voltage electrical discharges, pulsed electric field, and ultrasound assisted extraction of protein and phenolic compounds from olive kernel. Food Bioprocess Technology, 8, 885-894.

https://doi.org/10.1007/s11947-014-1456-x

25. Sechi, N.S.M., Marques, P.T. (2017). Preparation and physicochemical, structural and morphological characterization of phosphorylated starch. Materials Research, 20(Suppl. 2), 174-180. https://doi.org/10.1590/1980-5373-mr-2016-1008

26. Sung, J.H., Park, D.P., Park, B.J., Choi, H.J., Jhon, M.S. (2005). Phosphorylation of potato starch and its electrorheological suspension. Biomacromolecules, 6(4), 2182-2188.

https://doi.org/10.1021/bm050146w

27. Tian, S., Sun, Y. (2020). Influencing factor of resistant starch formation and application in cereal products: a review. International Journal of Biological Macromolecules, 149, 424-431. https://doi.org/10.1016/j.ijbiomac.2020.01.264

28. Thirumdas, R., Kadam, D., Annapure, U.S. (2017). Cold plasma: an alternative technology for the starch modification. Food Biophysics, 12, 129-139.

https://doi.org/10.1007/s11483-017-9468-5
29. Thirumdas, R., Kothakota, A., Annapure, U., Siliveru, K., Blundell, R., Gatt, R., Valdramis, V.P. (2018). Plasma activated water (PAW): Chemistry, physico-chemical properties, applications in food and agriculture. Trends in Food Science and Technology, 77, 21-31.

https://doi.org/10.1016/j.tifs.2018.05.007

30. Vanraes, P., Nikiforov, A.Y., Leys, C. (2016). Electrical discharge in water treatment technology for micropollutant decomposition. In Mieno, T. (Ed.), Plasma Science and Technology - Progress in Physical States and Chemical Reactions, InTechOpen Ltd., London, UK. pp. 429-477.

https://doi.org/10.5772/61830

31. Xie, W., Shao, L. (2009). Phosphorylation of corn starch in an ionic liquid. Starch, 61(12), 702-708.

https://doi.org/10.1002/star.200800124

Submitted: 17 December 2020. Revised: 25 January and 12 February 2021. Accepted: 15 February 2021. Published on-line: 24 February 2021. 